The Geographical Journal of Nepal

Vol. 13: 69-90, 2020

Doi: http://doi.org/10.3126/gjn.v13i0.28153

Central Department of Geography,

Tribhuvan University, Kathmandu, Nepal

\title{
Women in foreign employment: Its impact on the left behind family members in Tanahun district, Nepal
}

\author{
Kanhaiya Sapkota \\ Central Department of Geography, Tribhuvan University \\ Email:k.sapkota@cdgtu.edu.np
}

Received: 20 November 2019; Accepted: 10 December 2019; Published: March 2020

\begin{abstract}
Though, the migration process and its impact in the household economy has been extensively studied in the academic sectors, but much less attention has been given to the impact of female labor migration on the family members who are left behind at home. This paper attempts to determine socio-economic structure of female labor migrants from Tanahun District of Gandaki Province, Nepal. Similarly, it also attempts to analyze the causes of female migration, process and dynamics of foreign labor migration and its impact on the left behind family specially children and elder citizens at home. For this purpose, 180 households have been purposefully selected from three municipalities and conducted household survey through snowball methods. According to the survey findings, married women are preferred to go for abroad, whereas the age of migration is after 30 years. Literate are very less migrated for foreign labor. Majority of the female migrants preferred to go to Gulf Cooperation Council (GCC) countries and then other countries, i.e. Malaysia, Lebanon, etc. There are both positive and negative impacts clearly observed. The positive impacts of remittance to support for the poverty alleviation at household level, enhance educational and health facilities as well as improve housing conditions. But, the negative impacts, especially on children are appeared, i.e. care deficit, aggressive behavior, physical abuse, deteriorating health condition and school dropout. To, eliminate or reduce negative impact, government should take initiation and formulate effective policies that can maximize positive effects.
\end{abstract}

Key words: Female migrant, foreign employment, Tanahun district, remittance, left behind family. 


\section{Introduction}

The migration process and its effect in the family and household economy has been widely considered in the scholastic segments, yet substantially less consideration has been given to the effect of female migrants on the left behind family members at home in the rural settings of Nepal. A large number of residents in the country confronting contracting monetary open doors at home, numerous Nepalese people have looked for work in a foreign country (Peskin, 2016). Thus, international labor migration has become an acknowledged avenue for financial development, both for the migrant's household and for the country. The trend of migration for foreign employment in Nepal can be traced back to 200 years ago but it was institutionalized only after the introduction of the Foreign Employment Act in 1985. In the last few years, the country has witnessed a unique political change but on the economic front, in comparison growth has remained almost stagnant. Poor economic growth and limited employment opportunities in the country have made foreign employment a forced choice for many.

Foreign labor migration from Nepal has extended consistently throughout the decades. Over the recent couple of decades, the quantity of females going abroad as work vagrant has gradually expanding (Sijapati, Mak, Zimmerman, and Kiss, 2019). In spite of the fact that the worldwide movement from Nepal began after 1990 (Bhadra, 2007), female migration as an international laborers' eminent presence just from 1990. As indicated by the CBS (2011) that the female migrants is about 12\% (Peskin, 2016) and this figure in India is 23.6\% (Wadhawan, 2018), just as Bangladesh is $49 \%$ though in the Philippines and Sri-Lanka is high i.e. 70-90\% (Luna and Islam, 2014). Formally, Nepal entered into foreign labor market bit lately and cover a very low percentage in comparison to total migration (Islam, 2009; Sapkota, 2018a; 2018b; 2018c). The international labor migration pattern rose particularly after the 1990s, chiefly because of the fast procedure of globalization and the changed financial and political settings inside the nation. However, female labor migration was verboten up to 2007 in the Gulf Cooperation Council (GCC) and other neighboring countries. Department of Foreign Employment of Nepal show that more than 176,000 women have been received permits for labor migration since 2008, and they intend to go to the UAE, Kuwait, Malaysia, Qatar, Saudi Arabia, Lebanon, Cyprus and Jordan. But the recent report produced by the same government organization that on foreign migration launched by the government of Nepal, an estimated 21,421 Nepalese women are legally working overseas as of 20142015 , mostly in the GCC countries (DoEF, 2016). In response to reports of the abuse of female domestic workers in the Gulf countries, Nepal declared that it is illegal for women to go there for domestic work in 2016. Still, in 2017, more than 20 thousand women were given permits for international labor migration other than maid works, 
which is almost nine percent more from the year before. Due to open border with India, numbers of women used Indian airport illegally to circumvent the ban by the Nepal government.

Foreign labor migration is a highly paid job choice for Nepalese people. According to the Department of Foreign Employment more than 350,000 Nepalese youth migrate from the country for foreign employment annually. They make significant contribution to the country's economy through remittance. From 2008 to 2017, Nepal gave some 3.5 million work grants to migrant workers. Dominant part of them for Malaysia and countries of the GCC. In the last fiscal year, Nepal received remittances worth NPR 699 billion (USD 6.56 billion) from its residents utilized abroad, more than one-fourth of national GDP, the fourth-most noteworthy extent in the world (Baruah and Arjal, 2018). The International Organization for Migration (IOM) takes note of that migration holds the possibility to rearrange gender relations and power chains or hierarchies by giving possibilities to people to modify their economic wellbeing, and bolster themselves and their abandoned relatives and family members. Nonetheless, researchers demonstrated that migration can expose to harsh working conditions, not well characterized legitimate status in an outside nation, physical and psychological health risks, and stigma upon come back to their origin (Peskin, 2016; Sapkota, 2019). The lack of economic opportunity in the country is a significant explanation that females are migrating abroad for work. In migration studies, since Ravenstein $(1885 ; 1889)$ detailed his migration laws, individuals are required to move from low-income to highincome regions. The idea that migration is a component of spatial disequilibrium is the foundation of supposed 'push-pull' models that still overwhelm a great deal of gravitybased movement displaying (Lee, 1966; Stark, 1978, 1991).Thus, push-pull factors for the most part distinguish different environmental and economic factors which are assumed to push migrants out of origin of birthplace and bait them into destinations. Other than the "pull" factor of potential monetary profit, different issues, for example, conjugal issues and gender discrimination, serve as "push" factors that inspire women to seek job opportunities for work outside of Nepal (Peskin, 2016). The monetary or the financial benefits of labor migration are apparent in the skyrocketing amount of remittances - cash sent home from Nepali work transients around the world, which are a major help to the individual households and the national economy as a whole.

For a long time, Nepalese men have been moving abroad for work. As of late, Nepalese women have also started looking for open doors for foreign employment, chiefly to ease poverty at home. Most of the female migrants look for work in the so-called "care economy" (Bhadra, 2007). In any case, because of sexual orientation separation, their relocation and the work aren't smooth, safe and additionally secure, from inside 
their homes/families and their country, through the country of transit to the country of employment (Bhadra, 2007).

The constitution of Nepal guarantees the fundamental rights of the citizens including their right to employment. It ensures citizens with the freedom to be involved in any kind of employment and have ensured freedom of movement for the citizens. Considering the social status of women in Nepal, the constitution has also clearly made provisions against gender-based discrimination. The Nepal Government's Three-Year Plan 201013 and the draft Approach Paper for the Three-Year Plan 2014-16 reinforces the need to make foreign employment safe, respected, organized and productive. The Concluding Observations of the Convention on Elimination of All Forms of Discrimination against Women (CEDAW) Committee 2011 includes specific recommendations to the Government of Nepal to protect the rights of women migrant workers. The Foreign Employment Act, 2007 and the Foreign Employment Policy, 2012 includes various provisions for the protection of the rights of women migrant workers. The Act further adopts the principle of non-discrimination in the processes of foreign employment.

Poverty, lack of decent economic opportunities and violence are the root cause of the increasing number of women in foreign employment (Luna and Islam, 2014). Poverty along with the growing inequality in the living standard of the people in Nepal has let female to go for the foreign employment as for better prospects of life. However, they have limited access to training and education as well as limited rights on decision making power concerning their mobility. Even such harsh conditions, Nepalese women migrants have been managing works/jobs in many countries, i.e. working as domestic services. Official figures show that the percentage of women officially leaving for foreign employment has risen to around $6 \%$ in the year 2012 compared to 3\% in the year 2011 (DoFE, 2016). Lack of information and attractive offers made by agents has misled many women to migrate unofficially via other countries for foreign employment. This trend is making women more vulnerable to abuse and exploitation. In addition, most women are employed as domestic workers. This sector is not covered by the labor laws of many countries of employment which further increases their vulnerability. To address this issue, International Labour Organization (ILO) Convention 189 on Decent Work for Domestic Workers came into force in 5 September, 2013. The existing structural inequality increases women's subordination and prevents women from accessing employment opportunities. Breaking stereotypical norms, women migrant workers have established themselves as the bread-winners of their families and have been contributing financially to their families 'sustenance and the country's economy. 
Studies found that remittances sent home by female migrant laborers were regularly utilized for day by day household necessities, kids' education, health services, construction of new house or resettlement in urban areas, and advance reimbursements of their loan (Battistella, and Conaco, 1998; Peskin, 2016; Acharya, 2017; Sapkota, 2018a; 2018b; 2018c). Researchers have noticed that remittances can have impacts beyond increased household spending: they can impact mentalities toward gender roles and women's participation in the labor market and the amount Nepalese women have earned helped to improve their social and financial status inside their families and their societies. Notwithstanding that, female migrants enable to gain social skills, exposure and experiences to the outside world just as their lives might have the option to experience a new freedom. Be that as it may, another account which female migrants face in the external world is very nosogenic and maddening. A framework where low-skilled female migrant laborers migrate abroad to help their families, frequently with uncertain prospects at their destination, has innate potential for abuse i.e., from enlistment misrepresentation, to sexual abuse, to human trafficking, and so on and loads of harsh stories we much of the time read in the national daily papers in Nepal.

Migration is a phenomenon that has a multi-confronted sway on people, families and social orders on their economies and cultures, both in the spot of home and away (Carballo, Divino, and Zeric, 1998). It leads to upgrade of the prosperity of migrants just as that of their families (Stark and Taylor, 1991; Chant and Radcliffe, 1992; Kahn et al., 2003). In general, the advantages of migration are all around reported, prevalently the economic benefits of remittance. It generates financial and social impact to the migrants and the nation (IOM, 2009). Studies have acknowledged that migration leads better health among the left behind family members (Gulati, 1993; Hadi, 1999; Kuhn, 2003; Sapkota, 2019). Unexpectedly, numerous studies have discovered that female labor migration, which is growing, has a solid negative effect on the left behind children (UNICEF, 2008; Luecke and Stoehr, 2012). Nonetheless, women have commonly been seen as increasingly dependable migrants, remitting a larger portion of their earnings, staying in contact all the more as often as possible, and staying trustworthy to their accomplices and families. Study recommended that health and behavioral risks are more common among youngsters living in the migrant's households.

Nepal is one of the key labor providers for GCCs, Other Middle East countries, as well as Korea, Malaysia, etc. Majority of the migrants are male but the females are also getting permits for international migration for work, while the exact numbers and the types of work are under-researched. More than 21 thousand females were reported as legitimately emigrating for work in 2014/15 (GoN, 2016), however real numbers are probably going to be more, the same number of female migrations through sporadic 
channels, and hence are not caught in official statistics (Ghimire, et al., 2010; Sijapati and Nair, 2014). Besides, these statistics don't catch the female migration to India, which is the main destination for female migrant workers from Nepal (World Bank, 2011), since labor permits are not required for movement between these two nations. Therefore, the present paper attempts to explore the international female labor migration and its impact on the left behind family members in their home. Studies on the impact of female labor migration on the left behind family members in Nepal are scant. There are very few inclusive studies that measure the impact of female labor migration on left behind family members, especially children or elderly people. Thus, this study fills up the research gap on the impact of female labor migration on the left behind communities in the study area.

\section{Methodology}

Tanahun District of Gandaki Province (Figure 1) has been purposefully selected for the study. In the middle hill districts, Tanahun ranked in the first share of the total migrants (Gartaula and Niehof, 2013; Khanal, Alam, Khanal, Regmi, 2015). This study covers three municipalities (Bhanu Municipality, Bhimad Municipality and Vyas Municipality) of Tanahun district. Bhanu and Vyas municipalities are located along the Prithvi highway, whereas Bhimad is little bit far from the highway but it is in the middle of Rampur of Palpa District and Vyas municipality. Among the municipalities, these three municipalities are leading in the number of female labor migrants in Tanahun district. Therefore, these municipalities have been selected for this research. The municipalities represent people in both traditional agricultural occupation as well as choose migration as a livelihood strategy. The study area is known as municipality, though agriculture still remains the primary occupation for a majority of the dwellers, and international labor migration has also become a prominent factor. This research is focused on the female labor migration from the selected municipalities and the households who have female members migrating outside the home District of Tanahun and remaining at least six months outside their home were considered the migrating households. 


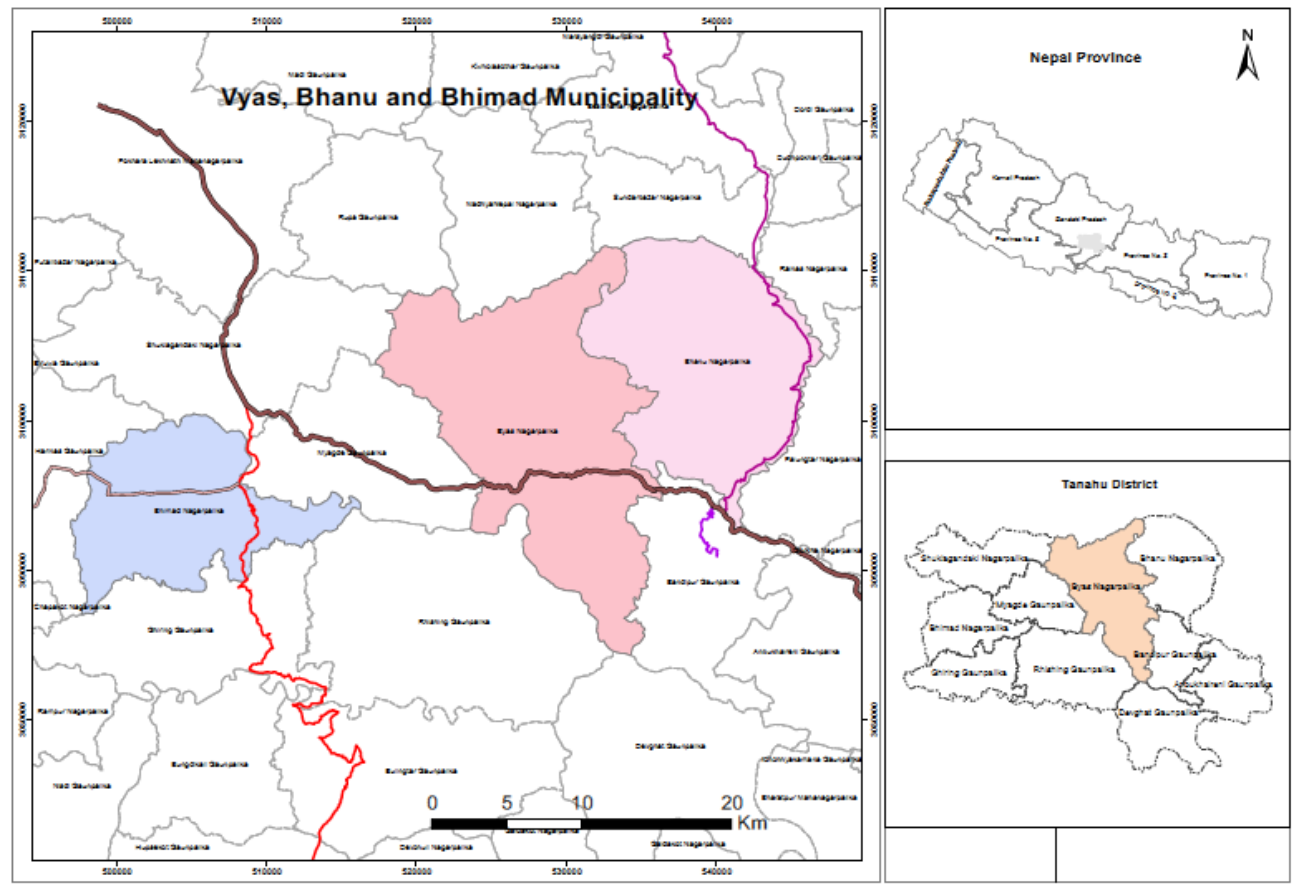

Figure 1: The study area

In this study, both primary and secondary data have been used. Mainly the secondary data has been collected from the government official documents, books, journal, research reports, etc. and the questionnaire survey was a major source of primary data. Data was collected using qualitative research methods, such as observation, focus group discussions (FGDs), in-depth interviews, and key informant interviews. The field work involved in-depth interviews with 20 family members of the female migrants, focus group discussions with three separate groups in three different locations of the selected municipalities and nine key informant interviews with government representatives, local leaders, teachers and the representatives from labor migration agencies. According to the municipality records, until 2017 A.D. of the selected municipalities, altogether 485 females were applied for foreign labor migration (MoLE, 2018). For the quantitative data collection, the household survey was conducted in September-October 2019 from the family members of female migrant workers. Snowball samplings have been adopted for survey work and one hundred eighty (180) households have been selected through this method. Out of 270 households, almost 14\% (38 households) are shifted or relocated in other districts during this study period. Thus, for the survey purpose almost 78 percent 
households have been selected. The interviews with the husband or adult members of the migrant's family have been selected for reliable and authentic information.

Table 1: Sampling frame

\begin{tabular}{|l|l|l|r|r|}
\hline Municipalities & $\begin{array}{c}\text { No. of female } \\
\text { applicants for } \\
\text { foreign labor } \\
\text { migration (Until } \\
\mathbf{2 0 1 7}\end{array}$ & $\begin{array}{c}\text { Relocated/ } \\
\text { shifted HHS } \\
\text { from the } \\
\text { origin }\end{array}$ & $\begin{array}{c}\text { Remaining } \\
\text { HHs }\end{array}$ & $\begin{array}{c}\text { Sample } \\
\text { households }\end{array}$ \\
\hline Bhanu & 73 & 7 & 66 & 49 \\
\hline Bhimad & 81 & 17 & 64 & 54 \\
\hline Vyas & 116 & 14 & 102 & 77 \\
\hline Total & 270 & 38 & 232 & 180 \\
\hline
\end{tabular}

Source: *MoLE, 2018

Before household survey, research ethics have been fully considered and without consent of the respondent the survey was not conducted. Similarly, no-harm to the informants was also seriously applied. All of the statistical information has been processed, analyzed and presented in tables and interpreted them in descriptive manner. Though, this study does not cover the female migrant workers working in India because of the open boarder, do not have any official records of them.

\section{Result and Discussion}

\section{Demographic characteristics of the migrants}

In this section, female migrants' demographic characteristics, i.e. age, marital status, religion and education qualification are discussed. The government of Nepal has been specified the age limit for women who intend to go to the Gulf and other countries for work has come under criticism from human right activists. Only women who are aged 24 and above are eligible to work in the Gulf countries and for mothers, their children must be over two years of age. However, the government recently revised the age of migration. Now, 30 years and above female can be migrated for work abroad (Table 2). 
Table 2: Demographic characteristics of female labor migrants

\begin{tabular}{|c|c|c|c|}
\hline & Variables & $\mathbf{N}$ (at present) & Percentage \\
\hline \multirow{6}{*}{ Age group (years) } & Less than 24 years & 24 & 13.33 \\
\hline & 24 to 30 & 55 & 30.56 \\
\hline & 31 to 35 & 52 & 28.89 \\
\hline & 36 to 40 & 35 & 19.44 \\
\hline & More than 40 years & 14 & 7.78 \\
\hline & Total & 180 & 100.00 \\
\hline \multirow{5}{*}{ Marital Status } & Married & 146 & 81.11 \\
\hline & Unmarried & 9 & 5.00 \\
\hline & Divorce & 19 & 10.56 \\
\hline & Widow & 6 & 3.33 \\
\hline & Total & 180 & 100 \\
\hline \multirow{5}{*}{ Religion } & Hindu & 162 & 90.00 \\
\hline & Muslim & 12 & 6.67 \\
\hline & Christian & 4 & 2.22 \\
\hline & Others & 2 & 1.11 \\
\hline & Total & 180 & 100 \\
\hline \multirow{8}{*}{ Education } & Up to primary level & 31 & 17.22 \\
\hline & No formal education & 69 & 38.33 \\
\hline & Able to read only & 13 & 7.22 \\
\hline & Basic level education (1-8) & 48 & 26.67 \\
\hline & High school level (9 -12) & 14 & 7.78 \\
\hline & College level & 3 & 1.67 \\
\hline & University level & 2 & 1.11 \\
\hline & Total & 180 & 100 \\
\hline
\end{tabular}

Source: Field Survey, 2019.

This study found that almost thirteen percent female migrant workers age was less than 24 years. More than one third (30.56\%) of the female migrant workers were in between the age of $24-30$ years, $28.89 \%$ were in between the age of 31-35 years, and almost $20 \%$ were in between the age of 36-40 years and only about $8 \%$ migrants' age were above 40 years. But the government policy clearly indicated that the female who intend 
to migrate for work to abroad must more than 24 years before three years and now it is 30 . Thus, either they provided false age or left behind family members provided wrong information about the migrants' age. Similarly, most of the female migrants who intend to go abroad for work were married $(81.11 \%)$, while; only about five percent were unmarried. Almost, 14 percent of the female migrants were divorce and widow. In addition to that, 90 percent of the migrants were from Hindu religion while almost seven percent were from Muslim and rests of them were Christian (Table 2).

Considering the educational status, among the female migrants almost $38 \%$ had no formal education, while about $17.22 \%$ female migrants completed up to primary level education and $26.67 \%$ were completed their basic level education. Similarly, high school level education completed by $7.78 \%$ and the college and university level completed by almost three percent (Table 2).

\section{Push factors for migration}

In general, majority of the female migrate as workers or with their families, obsessed by economic stipulation. The failure of states to fulfill economic, social and political human rights play a key role in pushing women to migrate (WMN, 2017). Thus, this paper intends to highlight the issues to create an environment where women can choose to migrate or remain at home. Females are progressively moving on their own, often to upgrade financial open doors by looking for employments or education. The data demonstrate that the pace of female migration is becoming quicker than male in numerous nations that get elevated levels of migrants. This pattern is regularly alluded to as the "feminization of migration." The ILO estimates that female is half of the worldwide migrant population yet in certain nations account for 70-80 percent of migrants.

Until the late 1970s, comprehensive set of international migration either centered expressly just around male or appeared to expect verifiably that most migrants were male. That supposition was especially common when consideration was centered around the economic aspect of international labor migration, since it was broadly accepted that the partition of female in the international labor migration was insignificant.

Obviously, such beliefs were once in a while dependent on measurable proof since, both at that point and now, information on international migration regularly were not classified by sex. Thus, when researchers started to point out the support of female in international labor migration, one of their tasks was to discredit those convictions. 
Table 3: Reasons for migration

\begin{tabular}{|l|r|r|}
\hline \multicolumn{1}{|c|}{ Reasons } & No. of respondents & \multicolumn{1}{c|}{ Percentage } \\
\hline Alleviation of household's poverty & 76 & 42.22 \\
\hline Better education for children & 34 & 18.89 \\
\hline Family pressure & 32 & 17.78 \\
\hline Better earning opportunities & 21 & 11.67 \\
\hline Rejected by family/husband & 7 & 3.89 \\
\hline Widow & 3 & 1.67 \\
\hline Others & 7 & 3.89 \\
\hline Total & 180 & 100.00 \\
\hline
\end{tabular}

Source: Field Survey, 2019

Most of the respondents (42.22\%) mentioned household poverty as the main reason for migration. Every so often, due to unemployment, their husband or household heads inspire them to migrate, as female migration cost is relatively less than the male in Nepal. A significant proportion $(18.89 \%)$ opined that they choose international labor migration for their children's education and for their quality of life in future. In addition to that, family pressure is another important push factor for women to migrate abroad $(17.78 \%)$, because of the large family size and low family income. Approximately $11.67 \%$ of the female migrants went as labor migrants because of their limited job opportunities at home. However, it is very serious issue, that is about rejected by the family or husband, and the widows are compelled to migrate because they do not have any alternative helping hands for their everyday life and the livelihood. The rest, 3.89\% of the female are migrated because of other social driving forces which they could not tolerate or avoid (Table 3).

\section{Investment plan for migration}

In recent literature, explored a number of factors idiosyncratically affecting the international labor migration of women (Siddiqi, 2003; Islam, 2009; Luna and Islam, 2014; Acharya, 2017; Baruah and Arjal, 2018; Sijapati, Mak, Zimmerman, and Kiss, 2019). Some of the factors, such as women's need to escape doomed social situation, harassment, violence, poverty, and socially disadvantaged people who thought migration is primarily as a mission for freedom and a means of grasping self-reliance. However, in this study, one main reasons of female labor migration is that can reduce their poverty. 
Nepal, is one of the poorest countries in the world, where people have used migration as one of the strategies for poverty alleviation. Sapkota (2018) explored that remittance can help to alleviate poverty by rising productivity, making able to spend money for children's education and health of their families. From the study area, most of the female migrants are from economically poor family background and they are not able to manage a huge amount of money for travel and other necessary arrangement. Therefore, they managed only a very few amounts of money by themselves. In most cases they arranged money from different sources (Table 4), i.e. loan from bank/cooperatives, sale of land, mortgage of land, sale of valuable things, help from relatives, local money lenders, etc.

Table 4: Sources of money

\begin{tabular}{|l|r|r|}
\hline \multicolumn{1}{|c|}{ Sources } & \multicolumn{1}{c|}{ No. of HHs } & \multicolumn{1}{c|}{ Percentage } \\
\hline Loan from bank/cooperatives & 7 & 3.89 \\
\hline Sale land & 11 & 6.11 \\
\hline Mortgage of land & 26 & 14.44 \\
\hline Sale valuable things & 32 & 17.78 \\
\hline Help from relatives & 43 & 23.89 \\
\hline Local money lenders & 61 & 33.89 \\
\hline Total & 180 & 100.00 \\
\hline
\end{tabular}

Source: Field Survey, 2019

Nearly, 34\% arranged money from the local money lenders (sahu/mahajan ${ }^{I}$ ) with high interest rate. Similarly, $23.89 \%$ of the migrants' families took help from their relatives living the country. Selling valuable things, i.e. ornaments, livestock, etc. is another source of financial support for the migrants, which reported by $17.78 \%$ respondents. About $14.44 \%$ of the family took loan by giving through their land mortgage, while only $6.11 \%$ received money through land sale. Most of the migrants' family, they do not have sufficient land to sale or give mortgage in the study area. Due to official formalities and lengthy process, migrant families less preferred to borrow loan from the bank and cooperatives. Normally, it has difficult to repay the loan if it is taken with very high interest rate (Table 4).

1 Sahu/Mahajan used to describe the local people involved in money lending with high interest rate. 


\section{Where do they go}

The major destination countries of female migrant workers are the GCC countries, i.e. UAE, Kuwait, Qatar, Saudi Arabia and Bahrain and Malaysia in the east Asian countries.

Table 5: Destination countries

\begin{tabular}{|l|r|r|}
\hline \multicolumn{1}{|c|}{ Countries } & \multicolumn{1}{c|}{ No. of migrants } & \multicolumn{2}{c|}{ Percentage } \\
\hline Qatar & 25 & 13.89 \\
\hline Saudi Arabia & 24 & 13.33 \\
\hline Kuwait & 24 & 13.33 \\
\hline UAE & 22 & 12.22 \\
\hline Lebanon & 19 & 10.56 \\
\hline Malaysia & 16 & 8.89 \\
\hline Oman & 15 & 8.33 \\
\hline Cyprus & 9 & 5.00 \\
\hline Republic of Korea & 9 & 5.00 \\
\hline Bahrain & 4 & 2.22 \\
\hline Remaining countries & 13 & 7.22 \\
\hline Total & 180 & 100.00 \\
\hline
\end{tabular}

Source: Field Survey, 2019

It is appeared from the study that $13.89 \%$ of female migrant workers work in Qatar, which is followed by Saudi Arabia and Kuwait with $13.33 \%$ respectively. A considerable number $(12.22 \%)$ of female mingrants are working in UAE. After GCC countries, female migrant workers from the study area preferred to go to Lebanon $(10.56 \%)$ and Malaysia (8.89\%). Now-a- days, females are attracted in new destinations, i.e. Republic of Korea and Bahrain because of the high pay salary, though the number is relatively very less (Table 5).

\section{Where women work}

Ability in language is most important requirement to work competently in the overseas. This study found that migrants do not have sufficient knowledge and vocational and technical skills. This research finds that the women who have been presently working abroad were housekeeper which comprises $67.22 \%$, whereas $17.22 \%$ are working as cleaner. Due to the dearth of vocational and technical skills as well as the ability to speak local language, most of the female migrants are working as domestic workers in 
the GCC countries. Due to the same reasons, female migrants are not able to contribute in the field of industry and sales department. Therefore, the lack of communication skill incumbers the possibility of migration in expanded sectors of employment (Table 6).

Table 6: Employment sector

\begin{tabular}{|l|r|r|}
\hline \multicolumn{1}{|c|}{ Type of work } & No. of migrants & \multicolumn{2}{c|}{ Percentage } \\
\hline House keeper & 121 & 67.22 \\
\hline Cleaner & 31 & 17.22 \\
\hline Industrial labor & 12 & 6.67 \\
\hline Sales attendants & 10 & 5.56 \\
\hline Others & 6 & 3.33 \\
\hline Total & 180 & 100 \\
\hline
\end{tabular}

Source: Field Survey, 2019

The vast majority of the GCC countries, the domestic workers are recruited from Nepal as well as other developing countries, i.e. the Philippines, Indonesia, Bangladesh, Sri Lanka, Ethiopia, etc. In spite of the fact that the numbers recruited from Nepal have varied because of temporary bans or confinements that the administration have forced in light of maltreatment against laborers or conflicts with the GCC authorities (Begum, 2014).

\section{Labor migration: Is it worth to Nepalese women}

In Nepal, the female migration is still stigmatized by the society and facing various and unexpected challenges both at home and abroad. Therefore, they have to struggle for their existence in the society. Indeed, even with their significant contributions to the family, they are yet to give any obvious space in family and less priority to include in such exercises.

The findings of the study clearly indicate that the gender migration process is different. Mainly, male migration in response to the requirements of industrial sectors, i.e. construction, manufacturing, agricultural sector like plantation, and female migration in response to the shortage of domestic and childcare workers with GCC countries as well as Lebanon, Malaysia and Cyprus. The rate of female migration in the industrial and business sectors are very low (Table 6). Thus, the nature of the problem facing by the female labor migrants are also different.

Female labor migrants face a major risk that includes sexual exploitation, trafficking and violence. However, all migrants are vulnerable to be abused and exploitation, but 
particularly female migrants are at risk. Almost $86 \%$ of the respondents told that the female member of their family who is working abroad is facing sexual exploitation and violence. Majority of the female migrants are working as domestic workers and they reported that they are facing such type of problem by their owner at the host countries.

In addition to that, women migrants from the study area face double discrimination as women and as migrants. For example, racism and xenophobia are serious concerns in their destinations. Because of this reason, female migrants can suffer particularly from these attitudes, experiencing not only discrimination based on their migrant status but also on their gender. This can take the form of discrimination and harassment that include workplace sexual harassment.

Language barriers are another challenge for all migrants. Because of the lack of communication skills, they are not able to communicate properly with the house owners or any others at their destinations.

\section{Impact of migration on left behind family}

The impact of female labor migration has been examined extensively. The vast majority of the studies have focused on the impact of migration on the receiving countries and on migrants as well as their left behind family members. There are many sides to the determined debate over international labor migration of the female household member. While a lot of it focuses around the economic costs and advantages of migration in both home and destinations countries, considerably less is thought about the human side of the migration story. Deliberations on the landings of those migrants whose families are left behind is very crucial especially for the developing societies.

Generally, international labor migrants (either male or female) often leave their family members at home, since it is expensive for the entire family to move or exacting migration strategies and uncertain conditions in the places they are going. This study found that the impacts of female labor migration on the left behind family members can be both positive and negative, depending on whether the migrant is away temporarily or permanently and whether or not they remit money back home regularly. Migrants often send money home that help to those who left behind by enhancement of their living standards. At the same time, migration could be disrupted family life, which could have adverse impact on the well-being of migrant-sending households living in the countries of origin. Leucke and Stoehr (2012) have identified that remittances raise household income and help to reduce poverty of the family. Left behind family members become able to use remittances in various sectors, i.e. better-quality food, construction or rebuild 
building, land purchase, expense their children's education as well as for health care of the left behind household members. In addition to that, the return of the migrant could also bring back valuable skills acquired abroad as well as entrepreneurial potential. These, positive impact of remittances compensates for some of the negative effects of the absence of the female migrant (Luna and Islam, 2014).

It is illustrated from the study that the remittance from female labor migrants helped to combat with the household poverty by $72.78 \%$ of the households by increasing their family income. It helps them to improve their financial security, which supports to improve social status/dignity in the community (Table 7).

Moreover, $62.22 \%$ of the left behind family members have changed or improved their children's educational performance through enhancing the facilities (better educational institution, quality teacher, etc.) by the remittances. In the study area, better education for children often means to get access in private school education. Getting more money from migrants, $47.78 \%$ of the left behind family members have changed their lifestyle through using modern amenities and home appliances. Better medical treatment specially for the senior citizens and children of the household reported by $38.33 \%$. Near to one third $(28.33 \%)$ respondents replied by using remittance they have developed the household conditions (i.e. renovation of the house, etc.). About $25.56 \%$ told about better food they started to consume in the study area.

Table 7: Impact of remittances ( $\mathrm{n}=180)$ - [multiple response possible]

\begin{tabular}{|l|r|r|}
\hline \multicolumn{1}{|c|}{ Positive impacts } & No. of HHs & \multicolumn{1}{c|}{ Percentage } \\
\hline Poverty alleviation & 131 & 72.78 \\
\hline Improvement educational facilities & 112 & 62.22 \\
\hline Change lifestyle & 86 & 47.78 \\
\hline Improve health care facilities & 69 & 38.33 \\
\hline Improve housing condition & 51 & 28.33 \\
\hline Increase food consumption pattern/rate & 46 & 25.56 \\
\hline Negative impacts & \multicolumn{3}{|c|}{} \\
\hline Care deficit & 114 & 63.33 \\
\hline Psychological well-being & 91 & 50.56 \\
\hline Deteriorating health & 64 & 35.56 \\
\hline Drop-out from school & 62 & 34.44 \\
\hline Aggressive behavior & 31 & 17.22 \\
\hline
\end{tabular}




\begin{tabular}{|l|r|r|}
\hline Physical abuse & 11 & 6.11 \\
\hline Starting anti-social activity of children & 8 & 4.44 \\
\hline Divorce of migrant & 2 & 1.11 \\
\hline
\end{tabular}

Source: Field Survey, 2019

In comparison with the various positive impacts, innumerable negative impacts were also found during this study (Table 7). For example, the study found that while the female migrants stay in contact with their left behind family members; children may lose the care as well as emotional support and guidance. The findings show that $63.33 \%$ of the respondents mentioned the care deficit of children which has adverse impacts. It seems that sometimes female member of the household absence does lead to changes in gender role and responsibility within the household, as sometimes male member look after the children while female member goes abroad for work. Psychological well-being is another negative impact of female labor migration to their children, which carries $50.56 \%$ of the households. Likewise, the family member from the female migrant households opined that the absence of mother hampers children's health condition as well as school performance. But the data indicates that mother absent children dropout rate is $34.44 \%$ because of the lack of proper care givers at home. Another negative impact is stressful or aggressive behaviors in the left behind children. As expected, the migration of the female family member was perceived by the children at the emotional level with a sense of loneliness and sadness. Almost 17.22\% respondents found children's behavior after their mothers' departure to abroad often aggressive or sadness, anger apathy or fear, etc. In addition to that, the risk of physical abuse and anti-social activities or rebellious activities appear in the children's behavior in the study area. In comparison with other negative impacts, the physical abuse and anti-social activities are not much serious problem, but to take it as solemn delinquent by the parents and care givers at home.

\section{Conclusion}

This study focused on the female labor migrants and its impact on the left behind family members. The data for this study were collected from three municipalities (Bhanu Municipality, Bhimad Municipality and Vyas Municipality) of Tanahun, western middle district of Nepal. The focus is to explore and analyze the impact on left behind family members and the children. In this research, the research design was mainly qualitative in nature, with mostly nominal variables which allow for limited statistical analysis. In this regard, this research paper has been mostly descriptive. Therefore, this paper attempts to suggest direction of the tendencies rather than conclusions. 
One important aspect of this study is family dynamics, which is created by international labor migration. In addition to that, one of the most important finding of this study is that the absence of mother has the most disruptive effect in the life of the children. However, intricacies of mothering by father are better prepared for, and pay more attention to. Thus, children without their mothers seem to have more problems, like care deficit, psychological well-being, aggressive behavior and physical abuse.

Female labor migration is relatively a recent phenomenon and abroad opportunities for women to feel empowered and the possibility to gaining respect and status due to the remittances they are able to send back their home. Due to the lack of employment opportunity, low income of the family along with the large family size their husbands inspire them to go for work abroad. Regarding female labor migration issues, there are so many fundamental persuading factors such as poverty, family pressure, and income opportunities etc. to be addressed. Female labors from Nepal are mainly concentrated in GCC countries as well as East Asia and some of the Middle East countries. Majority of them are working as care givers or domestic workers (house maid). In the study area, married and illiterate females are migrated as international labor migrants and they do not have language and communication skills. Due to the lack of communication knowledge and hence, they tend to be exploited. Thus, the vast majority of the female migrants involved as housekeeper since lack of knowledge and skill regarding other vocational and technical aspects. Scandalously, migrant workers face numerous threats and risks. Regarding the situation faced by migrants, Nepalese women have reported sexual, physical, and emotional abuse or salaries far below what a negotiator may have assured. Another serious matter is repaying the loan which is very difficult because they arrange money from local money lenders with high interest rate. However, it is very much encouraging that the workers coming from less educated families are motivated in using proper or formal channel for remitting the hard-earned money and rest of the female migrants used informal channel like $h u n d i^{2}$ to send money to their families. Along with savings, women intend to use their remittances to daily household necessities, health, children's education, home construction, and loan repayments. However, the greater part of the remittances to use as repayment their loan. Both, positive and negative impacts have been clearly observed and analyzed in this study. Positive impacts, i.e. alleviation of poverty, improvement education quality, improve lifestyle, and health care is some of the examples have been observed. Left behind children face numerous adverse effects of female migration including problems related to care deficit, psychological problem, health, education, aggressive behavior, physical abuse and anti-social activities due to the lack of motivation from others at home.

2 Hundi is an informal money transfer system that uses close networks to transfer cash without actually doing a cross-border transaction. 
Finally, for the proper channelization of the female labor migration, the country needs to formulate effective policies that can make best use of positive effects of migration. The policy that include the pros and cons of migration especially for female and need to provide clear orientation to them. For the sustainability of female labor migration, it is necessary to the policy makers and other stakeholders to have a clear picture on the profile of female migrants, the social cost of migration as well as the benefits of the female labor migration issues and its relation with their means of support. Therefore, in some families' migration is at least a temporary way out of a difficult or intolerable situation. Both aspects of migration's impact, extended family's roles and spousal relations are to be taken into profound consideration while formulating policies, plans and programmes so as to make the best use of positive effects of female labor migration.

\section{Acknowledgements}

I express sincere thanks to two anonymous reviewers from their careful reading of my manuscript and many insightful comments and suggestions. I am also much obliged to acknowledge Mahila Ojshwi Manch, Kathmandu for providing the financial support for the field work. Finally, my deep appreciation goes to cooperating households for their participation and cooperation during the study. In addition to that I would like to thank our PhD scholar Sher Bahadur Gurung for providing me a beautiful and relevant map for this paper.

\section{References}

Acharya, G. (2017). The impact of female labor migration from Nepal. Development Discourse, 4 (2): 41-52.

Amnesty International (2011). False promises: Exploitation and forced labor of Nepalese migrant workers. London: Amnesty International.

Baruah, N. \& Arjal, N. (2018). Nepalese labor migration: A status report. San Francisco: The Asia Foundation.

Battistella, G. \& Conaco, M. C. G. (1998). The impact of labor migration on the children left behind: A study of elementary school children in the Philippines, Sojourn. 13 (2): 220-241.

Begum, R. (2014). I already bought you: Abuse and exploitation of female migrant domestic workers in the United Arab Emirates. UAE: Middle East and North Africa of Human Rights Watch.

Bhadra, C. (2007). International labor migration of Nepalese women: The impact of their remittances on poverty reduction. Asia-Pacific Research and Training 
Kanhaiya Sapkota/ Women in foreign employment: Its impact on the ... Vol. 13: 69-90, 2020

Network on Trade (ARTNeT). Working Paper Series, No 44, September 2007. Bangkok: ARTNeT.

Carballo, M., Divino, J. J. \& Zeric, D. (1998). Migration and health in the European union. Tropical Medicine \& International Health, 3 (12): 936944. online journal NCBI. https://www.ncbi.nlm.nih.gov/pubmed/9892278.

Chant, S. \& Radcliffe, S. (1992). Migration and development: The importance of gender. In S. Chant (Ed.), Gender and migration in developing countries, 1-29, New York: Belhaven Press.

DoFE (2016). Labor migration for employment-Status report 2014/15. Department of Foreign Employment, Ministry of Labor and Employment http://www.dofe.gov.np/new/download/download_document/38

Gabriel, B. (2009). Migration: Advantages and disadvantages. Leaf Group Ltd. Retrieved from: peopleof.oureverydaylife.com.

Gartaula, H. N. \& Niehof, A. (2013). Migration to and from the Nepal Tarai: shifting movements and motives. The South Asianist, 2 (2): 28-50.

Ghimire, A., Upreti, B. Gurung, $G \&$ Adhikari, J. (2010). Nepal migration year book 2009. Kathmandu: Nepal Institute of Development Studies.

GoN, (2016). Labor migration for employment, A status report for Nepal: 2014/15. Kathmandu: Government of Nepal (GoN), Ministry of Labor and Employment.

Gulati, L. (1993). In the absence of their men: The impact of male migration on women, London: Sage publications.

Hadi, A. (1999). Overseas migration and the well-being of those left behind in rural communities of Bangladesh. Asia Pacific Population Journal, 14: 43-58. https:// www.researchgate.net/publication/11128015_Overseas_migration_and_wellbeing_of_those_left_behind_in_rural_communities_of_Bangladesh

IOM (2009). Gender and labor migration in Asia, Geneva, Switzerland: International Organization for Migration (IOM).

IOM(2017). The key terms of migration. Geneva, Switzerland: International Organization for Migration (IOM).

Kahn, K., Collinson, M., Tollman, S., Wolff, B., Garenne, M. \& Clark, S. (2003). Health consequences of migration: Evidence from South Africa's rural Northeast, South Africa: University of the Johannesburg. 
Khanal, U., Alam, K., Khanal, R. C. \& Regmi, P. P. (2015). Implications of out-migration in rural agriculture: A case study of Manpang village, Tanahun, Nepal. The Journal of Developing Areas, 49 (1): 331-352. DOI: 10.1353/jda.2015.0012.

Lee, E. (1966). A theory of migration. Demography. 3(1): 47-57. Retrieved from http://www.jstor.org/stable/2060063.

Luecke, M. \& Stoehr, T. (2012). Country report: Moldova, the effects of migration in Moldova and Georgia on children and elderly left behind. Europe Aid project DCI-MIGR/210/229-604, Moldova.

Luna, S. S. \& Islam, Md. S. (2014). International female labor migration and its impact on family member left behind: A case study on Sadarpur Upazila, Faridpur. Oriental Geographer, 58 (2): 53-72.

MoLE, (2018). Labour migration for employment a status report for Nepal: 2017/2018. Kathmandu: Government of Nepal, Ministry of Labour and Employment, Department of Foreign Employment.

Peskin, A. (2016). Out of Nepal: Women's labor migration. Features, Women Across Frontiers, Inc. New York: Issue 4. https://wafmag.org/2016/06/nepal-womenslabor-migration/

Ravenstein, E. G. (1885). The laws of migration. Journal of the Royal Statistical Society, 48 (2): $167-227$.

Ravenstein, E. G. (1889). The laws of migration. Journal of the Royal Statistical Society, 52 (2): 214-305.

Sapkota, K. (2018a). Women in foreign employment: Constitutional freedoms to curtailed rights. The Journal of Himalayan Studies, 1 (1): 1-19.

Sapkota, K. (2018b). Geographies of domestic violence in rural spaces: Case of rural Nepali communities in the Tarai region. Invention Journal of Research Technology in Engineering and Management, 2 (6): 38-52.

Sapkota, K. (2018c). Migration as an agent of social change in the rural areas: A case of Banke District, Nepal. Invention Journal of Research Technology in Engineering and Management, 2 (7): 97-108.

Sapkota, K. (2019). Impact of remittances on the left behind families in Nepal: A case of Vyas Municipality, Tanahun District. Journal of the Korean Cartographic Association. 19 (2): 133-146. DOI: https//doi.org/10.16879/jkca.2019.19.2.133

Sijapati, B.\& Nair, P. (2014). Gender and safe mobility: Promising global and regional practices. Switzerland: International Organization for Migration (IOM). 
Sijapati, B., Mak, J., Zimmerman, C., \& Kiss, L. (2019). Nepali women's labor migration: Between protection and proscription. Migration Letters, 16 (4): 611624. DOI: https://doi.org/10.33182/ml.v16i4.847

Stark, O. (1978). Economic-demographic interactions in agricultural development: The case of rural-to-urban migration. Rome: FAO.

Stark, O. (1991). The migration of labor. Cambridge \& Oxford: Blackwell.

Stark, O., \& Taylor, J. E. (1991). Migration incentives, migration types: The role of relative deprivation. The Economic Journal, 101 (408): 1163-1178.

Thompson, A. (2017). The pros and cons of moving to a new country. Colorado, USA: GoAbroad.

UNICEF (2008). The impacts of migration on children in Moldova, policy, advocacy and knowledge management (PAKM), New York, USA: United Nations International Children's Education Fund (UNICEF).

Wadhawan, N. (2018). India labor migration update 2018. New Delhi: International Labor Organization (ILO). http://www.ilo.org/wcmsp5/groups/public/---asia/--ro-bangkok/---sro-new_delhi/documents/publication/wcms_622155.pdf

WMN (2017). Women in migration: Version for input in the third thematic consultations on the global compact on migration. Geneva: Women in Migration Network (WMN).

World Bank (2011). Large-scale migration and remittance in Nepal: Issues, challenges, and opportunities (Report No. 55390-NP). Washington DC: World Bank Bank Poverty Reduction and Economic Management Sector Unit: South Asia Region. 